\title{
Light Activated Resin Containing Organic Dyestuff
}

\author{
Junichi NAKAZATO, Kazuo ITOH and Sadao WAKUMOTO \\ Department of Operative Dentistry, School of Dentistry, Showa University, 2-1-1 Kitasenzoku, Ohta-Ku, \\ Tokyo, 145, Japan
}

Received on January 3, 1989

Accepted on September 15, 1989

The physical properties of experimental visible light-activated resins containing dyestuff, which could be quickly discolored by irradiation was, evaluated by analyzing light absorbance characteristics and measuring micro Vickers hardness. The experimental resin, which was prepared by mixing equivalent weights of Bis-GMA and triethyleneglycol-dimethacrylate, was colored by one of three organic dye stuffs, and camphorquinone and dimethyl-p-toluidine were added to activate polymerization. In the tested materials, the experimental resins containing Methylene blue and Nile blue A were discolored quickly after the start of irradiation, and this was considered to be useful for dental practice because an overfilled margin could be easily identified. The Vickers hardness number of the base resin decreased slightly by a level of $6 \%$ by adding the dyestuff.

Key words: Methylene blue, Nile blue A, Oxazine 1

\section{INTRODUCTION}

In the case of the plastic restorations, it has been widely recognized that tooth-colored composite resins are extremely useful, although the minute fin, which is overfilled on the surrounding tooth surface, is difficult to be identified. And, it is well known that such fins on unprepared tooth surfaces are fractured easily, resulting in marginal defects over $50 \mu \mathrm{m}$ which cause recurrent caries ${ }^{1)}$.

In order to improve such a disadvantage, a blue colored plastic film, which covered the neighboring tooth surfaces prior to enamel etching, and a red colored fissure sealant have been introduced in clinic $^{2-4)}$. The use of such colored materials, however, have not become popular, probably because of the difficulty in handling them and for cosmetic reasons.

Therefore, it is desirable to develop colored materials which will discolor during polymerization. The possibility of developing quick, color-changeable materials that can be polymerized by laser beam has been previously suggested, although the details of the dyestuff were not described ${ }^{5,6)}$. These experimental, colored resins were expected to be polymerized by the heat of relatively high energy laser beams.

It is speculated that such a discoloration of the resin might be developed without heating, if the dyestuff can be discolored by soft laser or the visible light of a marketed lump unit. The purpose of the present study is to examine the possibility of developing a color changeable resin which can be polymerized by a soft laser or by a lump unit used for marketed light activated composites. 
<smiles></smiles>

\section{(Methylene Blue)}<smiles>CCNC(=O)C1C=CC2=Nc3c(cc(N)c4ccccc34)OC2=C1</smiles>

\section{(Nile BIue A)}<smiles>CCN(C)c1ccc2c(c1)I=C[C@H](N(CC)CC)C=C2</smiles>

\section{(Oxazine 1)}

Fig. 1 The organic dyestuffs tested

\section{MATERIALS AND METHODS}

The organic dyestuffs used in this study are listed in the Fig. 1. They were employed because they absorb wavelengths in the spectrum which were of the $\mathrm{He}-\mathrm{Ne}$ laser? ${ }^{\text {? }}$.

The experimental base resin was prepared by mixing the equivalent weights of Bis-GMA and triethyleneglycol-dimethacrylate (TEGDMA)*, with an addition of a reducing agent, dimethyl-p-toluidine (DMPT), in the proportion of $1 \%$ by weight.

In the first stage, the polymerization and discoloration of the experimental resin containing a blue dyestuff at a concentration of $0.1 \%$ was examined by irradiation with a soft laser.

The experimental resin was poured into a teflon mold $4 \mathrm{~mm}$ in diameter and $10 \mathrm{~mm}$ in height, and then irradiated by using a He-Ne laser** for $40 \mathrm{~s}$. In this procedure, however, the experimental resin was neither polymerized nor discolored.

Therefore, in the next stage, camphorquinone was added to the above described experimental resin at a concentration of $1.0 \%$. The specimens were prepared by the same method as those in the first experiment, and they were irradiated using a marketed visible light lump

- Bis-GMA and the triethyleneglycol-dimethacrylate; Sinnakamurakagaku Co. Ltd.

*. Soft Laser 632 ; World Wide Lasers I nd, Geneva, Switzerland 


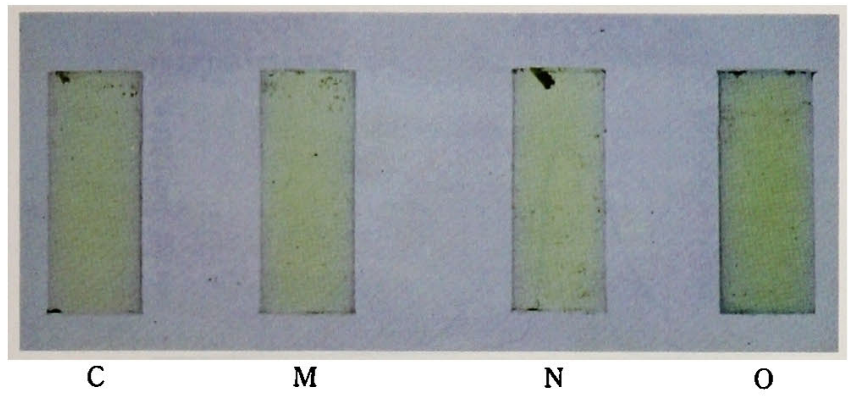

Fig. 2 Experimental resins after irradiated for $40 \mathrm{~s}$ by using a lump unit

$C$ : control resin composed of Bis-GMA, TEGDMA, camphorquinone and DMPT.

$M$ : experimental resin prepared by adding Methylene blue

$\mathrm{N}$ : experimental resin prepared by adding Nile blue $\mathrm{A}$

$O$ : experimental resin prepared by adding Oxazine 1
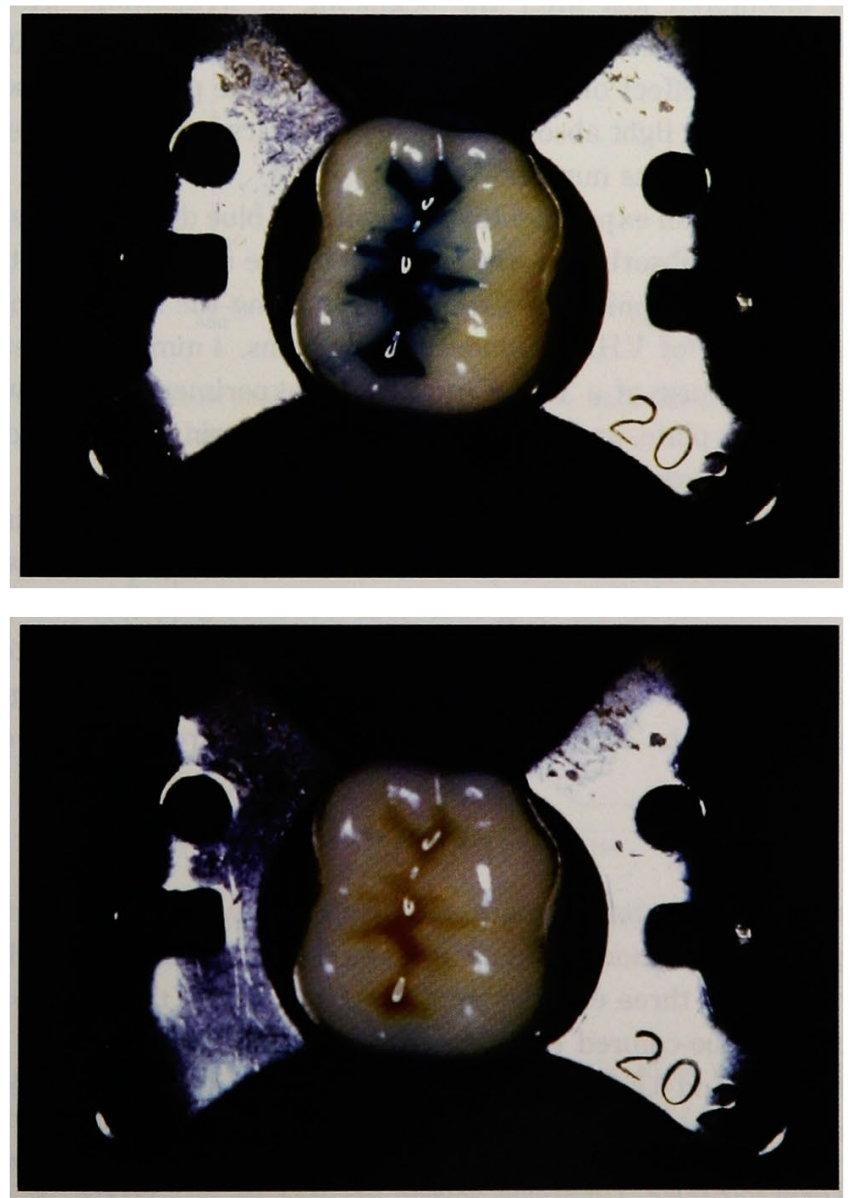

Fig. 3 Discoloration of the experimental resin containig Methylene blue

(a) : before irradiation

(b) : after irradiation 


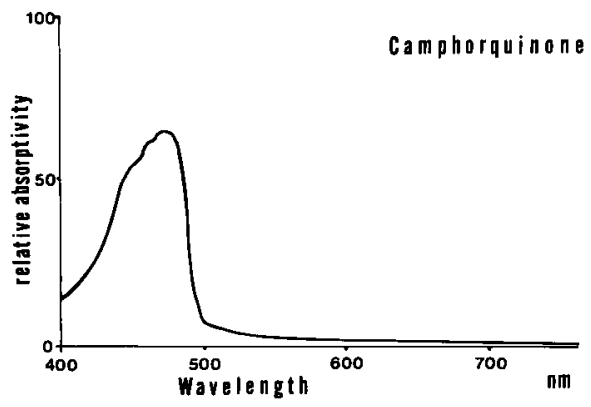

Fig. 4 The light absorbance characteristics of control resin composed of Bis-GMA, TEGDMA, camphorquinone and DMPT

unit*** for 20 or $40 \mathrm{~s}$. In this experiment, the blue-colored, experimental resins were polymerized and discolored just after the beginning of irradiation, with a exception of Oxazine 1 which was remained slightly blueish after irradiation (Figs. 2, 3).

In the final stage, the effect of the tested dyestuff on the physical properties of the resin was examined by analyzing light absorbance characteristics before and after irradiation, and by measuring Vickers hardness number (VHN).

For the control group, an experimental resin without blue dyestuffs was prepared and the characteristics of its light absorbance was analyzed by use of a spectrophotometer****. The light absorbance of the light unit was also measured using the same method.

For the measurement of VHN, cylindrical specimens, $4 \mathrm{~mm}$ in diameter and $10 \mathrm{~mm}$ in height, were prepared by use of a Teflon mold. The experimental resin was poured into a mold mounted on a glass plate, and the top surface of the resin was covered by another glass plate. The resin was then irradiated for 20 or $40 \mathrm{~s}$ by use of a lump unit ${ }^{* * *}$ with firm contact between the tip window of the lump and the upper glass plate. After storing for 24 hours in a dark room at a temperature of $24 \pm 1^{\circ} \mathrm{C}$, sections of the specimens were prepared by grinding half of the resin along the long axis with wet 1500 grit, silicon carbide paper. The VHN measurement of the resin was performed by using a hardness tester ${ }^{*}$ every $0.5 \mathrm{~mm}$ along the center of the sectioned surface. The VHN at each depth was given by the mean value of three measurements, and five specimens were prepared for each dyestuff.

\section{RESULTS}

The analyzed light absorbance characteristics are given in Figs. $4 \sim 8$. In the control group, a single peak of camphorquinone was observed at a wavelength of $470 \mathrm{~nm}$, and this peak was observed in the three experimental groups in which the blue dyestuff was added. Furthermore, for the blue-colored experimental materials, another peak was observed at wavelengths of 655,630 and $635 \mathrm{~nm}$, which were peculiar to Methylene blue, Nile blue A, and Oxazine 1 , respectively. No other peak was observed in this analysis.

\footnotetext{
*** Wite Lite; Tokuyama Soda, Tokuyama, Japan

**** EP-550 ; Nippon Bunko Co. Ltd. Tokyo Japan

" MVK-E; Akashi,Tokyo, Japan.
} 


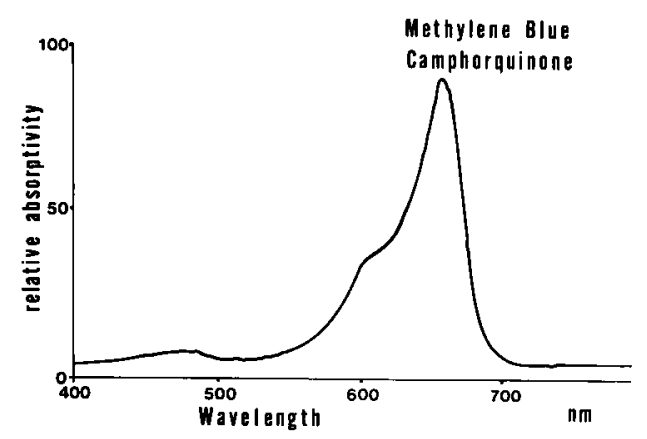

Fig. 5 The light absorbance characteristics of the experimental resin prepared by adding Methylene blue

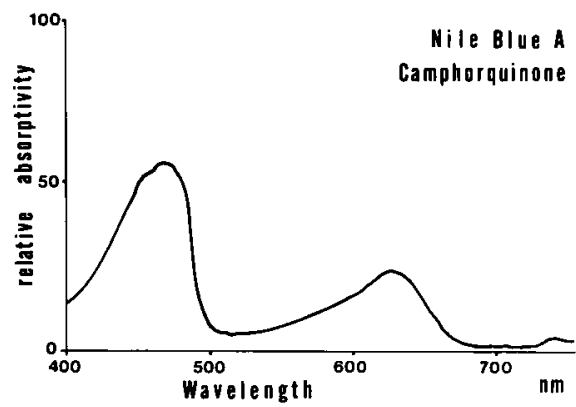

Fig. 6 The light absorbance characteristics of the experimental resin prepared by adding Nile blue $A$

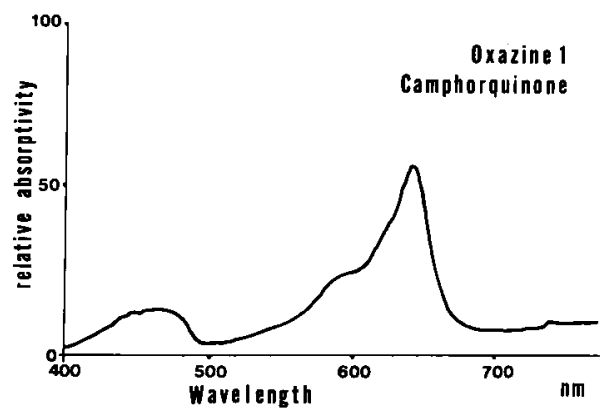

Fig. 7 The light absorbance characteristics of the experimental resin prepared by adding Oxazine 1

The results of the VHN measurement are presented in Figs. 9, 10. In the control group, the VHN increased by prolonging the irradiation time from 20 to $40 \mathrm{~s}$, and it decreased with the distance from the top surface. The same tendency was observed in the experimental groups, although the VHN was slightly smaller at a maximum value of $6 \%$ as compared with that of the control. 


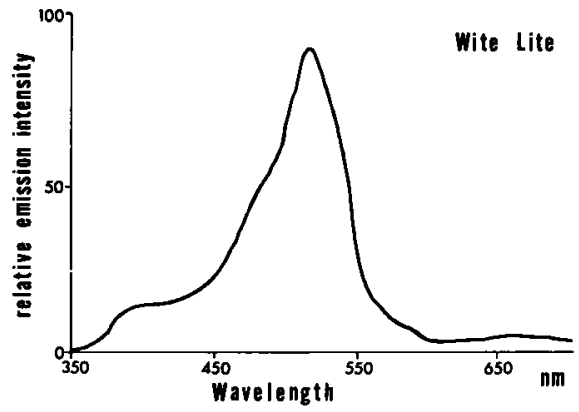

Fig. 8 The light absorbance characteristics of the lump source used in this study

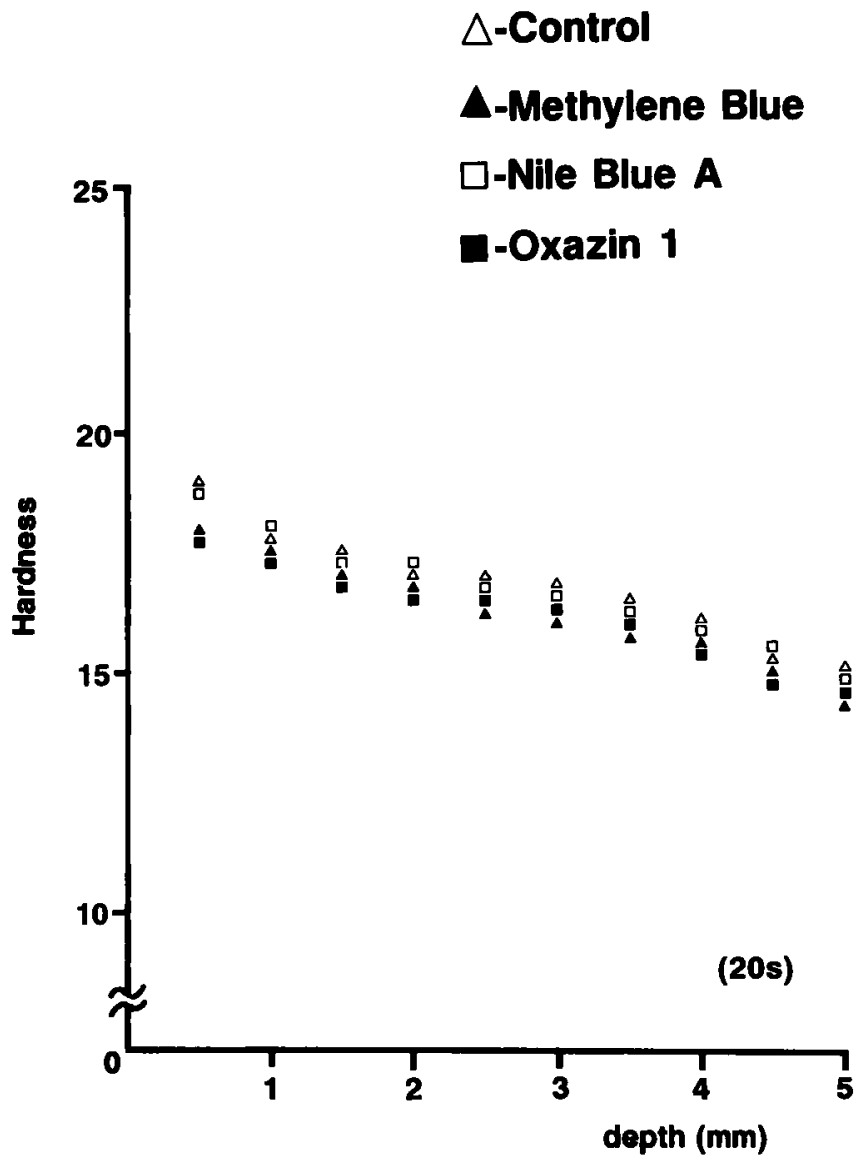

Fig. 9 The VHN of the experimental resins irradiated for $20 \mathrm{~s}$.

Number of the abscissa presents the distance from the top surface (mm). 


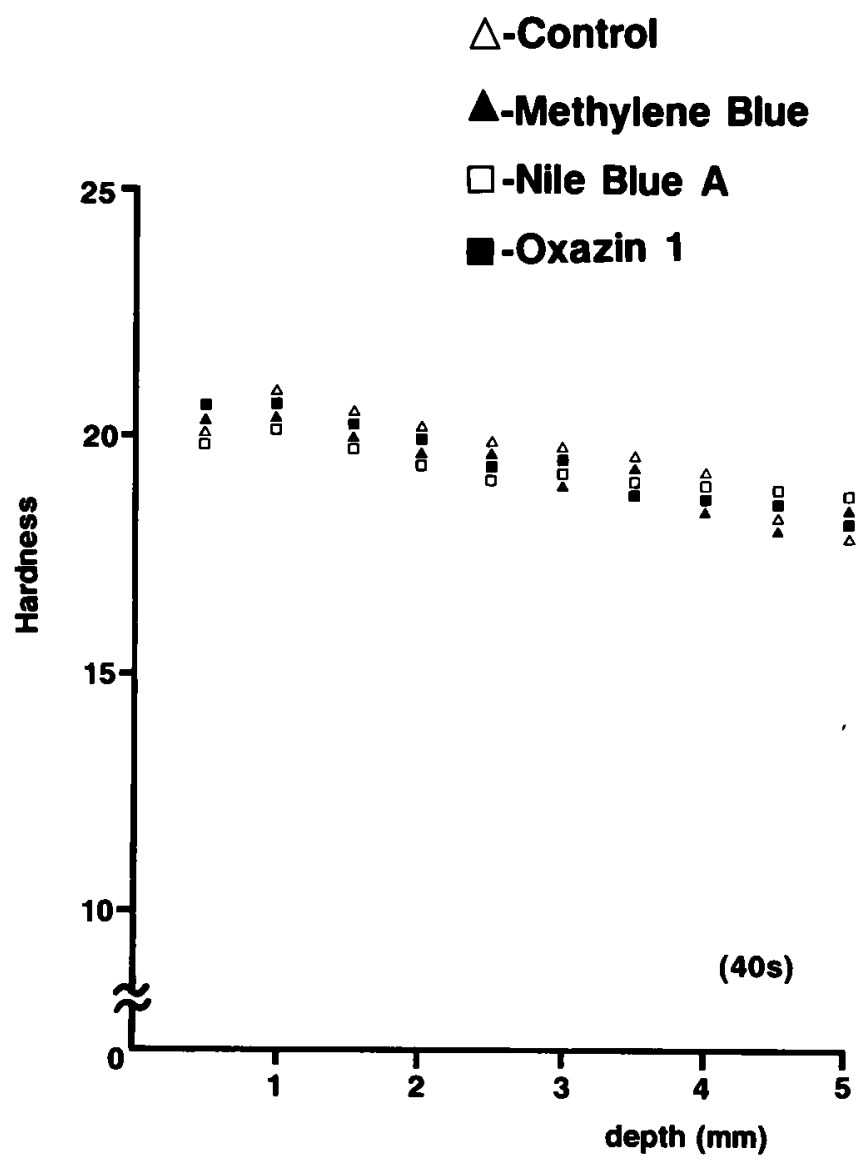

Fig. 10 The VHN of the experimental resins irradiated for $40 \mathrm{~s}$.

Number of the abscissa presents the distance from the top surface (mm).

\section{DISCUSSION}

Most of the marketed visible light curing contain small amounts of camphorquinone, tertiary amine as a photosensitizer, and a reducing agent to initiate polymerization. It has been previously revealed that the optimum wavelength of the light source should be adjusted to that of the light absorbance of camphorquinone. Therefore, wavelengths inherent in commercial halogen lump units which are unnecessary for polymerization were eliminated by using a blue-colored filter.

In the first experiment of this study, blue dyestuffs were employed because the characteristic wavelength of a He-Ne laser, although the experimental resin could not be polymerized because the energy of the soft laser only $6 \mathrm{~mW}$. Therefore, the experimental resin could not be polymerized by the soft laser.

Polymerization of the experimental resins prepared in the second stage was considered to be initiated by camphorquinone and DMPT, because two peaks of light absorbance 
characteristics, which are peculiar to camphorquinone and dyestuff, were observed and visible light with wavelengths over $600 \mathrm{~nm}$ were almost completely cut off. The discoloration of the dyestuff might be caused by a chemical interaction in the polymerization process between camphorquinone, DMPT, and dye.

The VHN of the experimental resins containing the blue dyestuff decreased slightly at a maximum level of $6 \%$ compared with that of the control. This effect was explained by the possibility that the transmission of visible light was limited by the dyestuff at an early stage of irradiation. This disadvantage, however, could easily be overcome by extending the irradiation time, as demonstrated in this study.

The experimental resin colored by Methylene blue and Nile blue A tested in this study was considered to be useful as a fissure sealant because the application area can be identified easily before polymerization.

\section{CONCLUSION}

In order to identify the overfilled marginal fin of resin material and to prevent recurrent caries caused by the fracture of an unsupported margin, an experimental resin, which contained blue dyestuff and became discolored just after the start of the visible light irradiation, was developed. Although the Vickers hardness number of the experimental resin composed of Bis-GMA and TEGDMA decreased slightly by adding the blue dyestuff, it was revealed that Methylene blue and Nile blue A could be discolored completely, and considered to be clinically practical.

\section{REFERENCES}

1) Wakumoto, S., Jørgensen, K, D. : Relationship between the marginal defects and the secondary caries on the class 1 amalgam restorations, Japan J Conserv Dent 14(1): 22-29, 1971. (in Japanese)

2) Kashiwagi, S., Tachikawa, Y., Hirano, Y., Nakata, M. : In vitro study of pit and fissure sealant (Part 1) Effect of marginal sealing and penetration into pit and fissure of sealant materials, Japan $J$ Pedodontics 25(1): 90-99, 1987. (in Japanese)

3) Kaneko, H., Imai, Y., Miyazawa, H., Imanishi, T. and Akahane, S. : A study on pit and fissure sealant (The etching effect that depends on the difference in the tooth-surface cleaning method, and the method of cleaning pits and fissures, Japan J Pedodontics 24(1): 1-12, 1986. (in Japanese)

4) Okano, Y., Doi, T., Hosino, M., Yanagawa, T., Morita, K., Hosoki, S., Watanabe, T., Hashimoto, K., Schimomura, H., Chiba, M., Toko, T., Moriya, H., Kato, H., Suzuki, T., Itho, K., Hisamitsu, H., Wakumoto, S.: Two year results of caries prevention restored by composite resins on first molars of lower classes school children, Japan J Conserv Dent 28(4) : 1313-1319, 1985. (in Japanese)

5) Kumazaki, M., Toyoda, K., Zennyu, K., Fujii, B. and Sasano, S. : Studies on laser polymerized composite resin (Part 1), Japan J Conserv Dent 28(1) : 202-209, 1985. (in Japanese)

6) Kumazaki, M., Toyoda, K., Zennyu, K., Fujii, B. and Sasano, S.: Studies on laser polymerized composite resin (Part 2) Reduction of irradiation energy, Japan J Conserv Dent 29(1) : 289-296, 1986. (in Japanese)

7) Masui, K., Nara, Y. and Katsuyama, S. : Studies on hardening sphere, hardness and clinical application of visible light-curing posterior restorative composite resins, Japan J Conserv Dent 28(4) : 1159-1182, 1985. (in Japanese) 
後の重量を計測することによって得られる，無機質フィ ラー含有量との相関を検討した。

その結果，無機質フィラーが 75 wt\%以下のコンポ ジットレジンでは, ギャッフが $0.09 \%$ 以下と比較的良好 な窒洞適合性を示したのに対し，75 wt\%以上になると
ギャップが $0.01 \%$ 示すコンポジットレシンがある反 面， $0.43 \%$ と極めて大きな值を示すものもあった。すな わち，無機質フィラー含有量が多くなるに従い，召洞道 合性が劣化する傾向がみられたものの, 両者間に性, 統 計的に有意な相関関係は見い出せなかった。

\section{有機色素を含有する可視光線重合型レジンに関する研究}

\section{——即時変色性レジンの開発 — \\ 中里淳一, 伊藤和雄, 和久本貞雄 \\ 昭和大学雷学部第二曾科保存学教室}

可視光線照射により即時に脱色する，各種有機色索を 含有した試作可視光線重合型レジンの物理学的特性の変 化を, 吸光光度計を用いた光吸収特性の分析と, 微小硬 度計による重合深度の計測によって検討した。

試作レジンは, Bis-GMA おょび Triethleneglycoldimethacrylate を等量混和することによって調慗し,重 合開始郕およひ僄元郕として Camphorquinone, Dimethyl-p-toruidineを添加して作製した。
その結果, Methylene blue, Nile blue A を含有した 試作レジンは，色素を加える事によって重合深度がわず かに低下したものの, 重合開始直後の脱色性に優九，充 塻時に特に辺緑部の過剩充坆を容易に識別でき,ひいて は過剩溢出の破折に上る二時门触を防止する事が容易と なるという利点から, 臨床応用も可能でると考えられ た。

歯質との接着に関する研究 その 6 MTYA を含む プライマーがコンポジットレジンと象牙質との接着に与える影響について 早川 徹, 遠藤 浩, 長塚明久, 堀江港三 日本大学松戸齿学部理工学教室

アルデヒドとしてグルタルアルデヒド, o-フタルアル デヒド, ホルムアルデヒドを用いて, それそれのアルデ ヒドと MTYA，HEMAからなるプライマーを調整し て，象牙筫とコンポジットレジンとの接着性を調へたと ころ, グルタルアルデヒドが接着性を向上させることが わかった。また, HEMAの代わりにエタノールを用いる と接着性が低下することも判明した。さらに,グルタル
アルデヒドの湌度を変えてプライマーを調整し接着性を 調べたところ、リン酸エッチング，クエン酸エッチング の場合にはグルタルアルデヒドの銥度によって接着強さ は影霎を受けた。

また,サーマルサイクル試験を行ったところ,リン酸 エッチングの場合, 2000 回後で接着強さが大きく低下し た。 